\title{
COVID-19 and the World of Work Dynamics: A Critical Review
}

\author{
A. M. Ogaboh Agba \\ Stepen I. Ocheni ${ }^{2}$ \\ Michael Sunday Agba ${ }^{3}$ \\ ${ }^{1}$ Department of Sociology, University of Calabar, Nigeria \\ ${ }^{2}$ Department of Accounting, University of Calabar, Nigeria \\ ${ }^{3}$ Department of Public Administration, University of Calabar, Nigeria
}

DOI: https://doi.org/10.36941/jesr-2020-0093

Abstract

COVID-19 has a profound impact on the world of work globally. It has altered the social fabric of the workplace and significantly accounts for the loss of normalcy in the world of work. As this threat continues, this paper sought to critically review the impact of COVID-19 on specific areas of the world of work. The study established the link between nCov and global loss of jobs. It critically examined how COVID-19 impacts on teleworking, occupational safety and health, workers mental health, discrimination, physical and social distancing at the workplace. Overwhelmingly, the paper concluded that COVID-19 exacerbates existing cracks in the world of work and its sustainability affects workers' mental health, social relations, escalate discrimination and unemployment globally. The study suggested policy reforms as global remediation to the negative impacts of COVID-19 on the world of work.

Keywords: COVID-19, the world of work, job loss, mental health, occupational safety, workplace discrimination

\section{Introduction}

COVID-19 is a global health and economic crisis that significantly altered the world of work. Consequently, millions of workers across the globe are battling with a loss of normalcy in their daily work lives. According to International Labour Organisation - ILO $\left(2020^{\mathrm{a}}\right)$ and United Nations Global Compact (2020), the pandemic, in addition to the threat to the economic, public health, and social disruption, profoundly affects the world of work and the livelihoods of millions of persons around the globe. As countries continue to mitigate the pandemic through lockdown measures, it impacts on the demand and supply sides of the labour market obstructs decent work and full-time employment.

While most employees lost their jobs and income, many others continue to work under very high health risks environment to produce essential goods and services for society (ILO, 2020 ${ }^{\mathrm{b}}$ ). Many women, especially in the informal sector, have continued to work, risking their health while some more are in vulnerable jobs with a high risk of losses and reduced labour hour (ILO, $202 \mathrm{O}^{\mathrm{C}}$ ). This situation widened the existing gulf of discrimination against women and introduced a novel gender inequality in the world of work. ILO $\left(\mathbf{2 0 2 0}^{\mathrm{d}}\right)$ argue that full or partial lockdown affects about 2.7 billion employees, representing 81 per cent of the global workforce. Again, an estimated global decline of 6.7 per cent in working hours which is equivalent to about 195 million full-time workers is 
expected in the second quarter of 2020.

COVID-19 has not only affected the world of work but have a profound impact on the physical and mental well-being of workers (World Economic Forum, 2020 ${ }^{\mathrm{a}}$ ). Employees are not left out, as millions of companies across the world are on the verge of being forced out of business with huge impacts on employment (United Nations Global Impact, 2020).

Although existing studies established the link between COVID-19 and the dynamics in the world of work, there is, however, scanty literature that provides an insight on how nCov is affecting specific units of the world of work. Again, there is a want of studies that provides policy options that will help address the negative dynamics in the world of work in the post-COVID-19 era. This study is posed to bridge these knowledge gaps by providing insight on how COVID-19 affects specific areas of the world of work such as occupational safety and health, telework, workers access to healthcare, discrimination and exclusion, flexible work and work schedule. The study is also set to make policy suggestions that will enable positive response of stakeholders to the changing world of work during and after COVID-19.

\section{COVID-19 and Global Job Lost}

COVID-19 is impacting negatively in the world of work. Half of the global workforce is at risk as job losses escalate due to COVID-19. As governments across the globe adopt lockdown measures to curb the spread of COVID-19, some 1.6 million employees in the informal economy (that is nearly half of the global workforce) are at risk of job loss. Workers in the informal sector also suffered massive damage in their capacity to make a living. For these set of workers, "no income means no food, no security, and no future" (United Nations News - UNN, 2020 ${ }^{\mathrm{a}}$ ). Four sectors whose workers are drastically and most affected are - manufacturing (with about 463 million workers), food and accommodation (144 million workers), business services and administration (157 million workers), and retail and wholesale ( 482 million workers). It is therefore apparent that the world of work is experiencing an extraordinary fall in employment level (United Nations News, 2020 $0^{\text {}}$ ).

Predicted global job loss in the travel and tourism industry as a result of COVID-19 by region shows that Africa (will decline 7.6 million jobs), Latin America (4.7 million jobs) and Middle East (2.6 million jobs). Other areas are - Caribbean (1.2 million jobs), Asia Pacific (63.4 million jobs), North America ( 8.2 million jobs), and Europe (13 million jobs) (see figure 1). The total number of predicted job loss in the travel and tourism industry alone is 100.8 million (Statista, 2020).

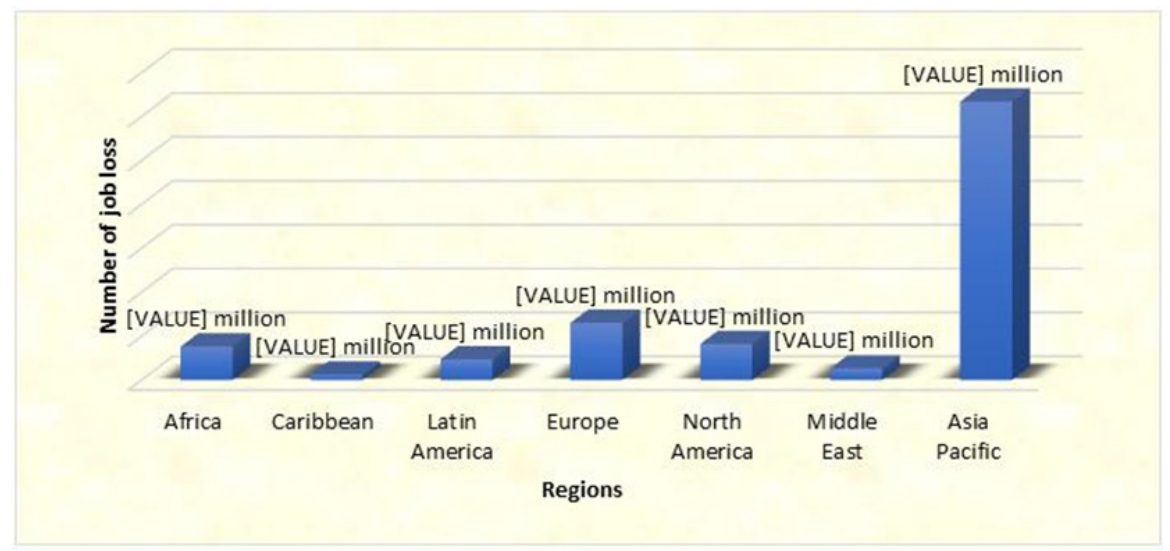

Figure 1: Predicted job loss by region in the travel and tourism industry due to COVID-19 pandemic Source: Statista (2020) 
Since COVID-19 pandemic outbreak, claims for unemployment benefits have soured in most $\mathrm{G}_{7}$ economies with the United States of America hitting about 30 million. The unemployment rate as in April 2020 is estimated at 15 per cent (World Economic Forum, 2020 ${ }^{a}$ ). The job loss is the steepest plunge in the United States of America since the great depression (World Economic Forum, 2020 ${ }^{\mathrm{b}}$ ). In Canada, 7.2 million people are out of a job, and the unemployment rate as a result of nCov is 13 per cent as in April 2020. The unemployment rate in Japan is about 2.5 per cent, with an estimated 1.76 million job loss. In Germany, unemployment has also risen phenomenally to 5.8 per cent leaving some 373,00o persons jobless as a result of the COVID-19 outbreak. In France, some 10 million workers, especially in the private sector, are affected. At the same time, the unemployment rate in the UK is predicted at 9 per cent because of the lockdown measures to curb COVID-19 (World Economic Forum, 2020 ${ }^{\mathrm{a}}$ ).

Globally, COVID-19 accounts for the devastating losses in working hours. It is expected that an estimated 6.2 per cent working hours will be wiped out in the second quarter of 2020, and this is equivalent to some 195 million full-time jobs. The Arab States are worst hit with an estimated 8.1 per cent working hours loss, equal to 5 million full-time jobs. This is followed by Europe 7.8 per cent equivalent to 12 million full-time workers. Similarly, considerable reductions in working hours are foreseen in Asia/Pacific, with an estimated 7.2 per cent equivalent to 125 million full-time jobs (see Table 1). Upper-middle income countries are also expected to loss of 7.o per cent working hours equal to some 100 million full-time workers (ILO, $2020^{\mathrm{e}}$ ).

Table 1: COVID-19 and estimated losses in working hours

\begin{tabular}{lcc}
\hline Regions/Income groups & Working hours loss in (\%) & Full-time working equivalent \\
Arab states & 1.8 & 5 million \\
Europe & 7.8 & 12 million \\
Asia/Pacific & 7.2 & 125 million \\
Upper-middle income countries & 7.0 & 100 million \\
\hline
\end{tabular}

Source: ILO $\left(2020^{\mathrm{e}}\right)$

\section{Effects of COVID-19 on Occupational Safety and Health}

Occupational safety and health is vital at any time and even more so, in this period of pandemic (Naden, 2020). Occupational safety and health entail the prevention of workers from occupational risks. It includes the provision of information and training and putting in place measures that improve existing safety and health situation (Kilinc Law and Consulting, 2020). With the COVID-19 outbreak, this practice in some organisations has been thrown upside down. According to the World Health Organisation - WHO (2020), the duties of health workers exposed them to hazards and are put at high risk of being infected by COVID-19. These job hazards include long working hours, exposure to pathogens, fatigue, stigma, physical and psychological violence, and occupational burnout. The outbreak of COVID-19 exacerbates health workers hazards as most of them work in an environment with insufficient measures for infection control and prevention. Consequently, WHO reported that as of $21^{\text {st }}$ April 2020, over 35,00o health workers were infected with COVID-19 globally. Similarly, Watterson (2020) argue that globally, and as a result of COVID-19 pandemic, dedicated social care and health workers, key support workers, service workers, and emergency workers put their lives at high risk to combat the pandemic.

The widespread of COVID-19 pandemic in the face of limited resources, acute shortage of staff has increased the level of physical and psychological violence against health workers. Also, security personnel, employees who help in contact tracing, testing and enforcement of social distancing to curb the spread of COVID-19 experience threats and attacks from patients and the public. These crops of workers are also experiencing long working hours, high workload, irregular work hours, and 
hard work (WHO, 2020). According to ILO $\left(2020^{f}\right)$, a large share of the world's working population spends a significant portion of their lives at the workplace and work environment. This suggests that the work environment and workplace condition the worker's well-being and family life. With COVID-19 outbreak, workers in essential duties spend even greater hours at the workplace than before; thereby exposing them to undue risks. Watterson (2020) posits that health workers are among the bulk of positive nCov cases, especially those in the frontline. Not giving them the required protection will endanger their lives and the fight against COVID-19.

Prolong exposure of health workers and other auxiliary staff in the test of COVID-19 and contact tracing has become a risk factor that promotes occupational diseases. Thus, coronavirus pandemic is a pointer to the importance of occupation safety and health, and the risk of exposing workers to undue health hazard (ILO, 2020 $\mathrm{g}^{\mathrm{g}}$ WHO, 2020). It is therefore clear that most transmission of COVID-19 is occurring at the workplace and work environment such as care facilities and hospitals. And with some transmission occurring between employees' and the public. There is also clear evidence that in most country's protective measures against COVID-19 such as personal equipment and social distancing are insufficient and in many cases, absent, thereby putting the worker in undue health risks (International Trade Union Confederation, 2020).

The use of gloves, hand sanitiser, and face-masks is a new-normal at workplaces to prevent workers from being infected by the nCov. Hand sanitiser dispensers are provided at the entry point of most organisations worldwide. Workers and clients are encouraged to conform with the new normal while interacting with each other either at the reception or meeting room. Strict hygienic rules are also introduced to keep workers and customers safe in most companies. Symbols and signposts are displayed to encourage stakeholder's adherence to hygienic rules and regulations.

\section{COVID-19, Social Distancing, and Social Presence at the Workplace}

The world of work is being affected by unprecedented measures put in place to curb COVID-19. Physical distancing and teleworking are reducing social presence that characterised work relationship before the outbreak of coronavirus. Sitting arrangement in major institutions, including legislative houses, courts, hospitals, manufacturing, among others, are changed to accommodate social distancing. Executive meetings of most federal agencies are done via video conferencing, thereby, eliminating all forms of social mixing at the workplace. Kiesha et al. (2020), argue that physical distancing is a proven and one of the most effecting measures in reducing coronavirus infection at the workplace. Social distancing can help reduce the level of spread at the workplace by 92 per cent when workers return to work. It is practical and very potent in reducing person-to-person contact and person-to-person transmission at the workplace and work environment.

COVID-19 continue to represents a challenge to the world of work on many levels despite the fact that remediation is slowly emerging. As restrictions are gradually being lifted, and workers begin to return to work, safety at the workplace becomes the next challenge to employers. This concern is changing the world of work in many ways; as novel social-relations policies are introduced at the workplace and are slowly becoming a new normal. COVID-19 informs social distancing, the use of remote workers and accelerates digital transformation in the world of work.

According to Ben-Itzhak (2020), coronavirus accelerates digital transformation at the workplace, and workers are undergoing the new experience of working remotely. He observes that COVID-19 complied some organisations to move their on-site workers to a permanent remote position, and this is helping these companies to achieve cost-saving benefits of the remote workforce. For instance, the Twitter company is now introducing a remote working policy that will enable employees in the organisation to work remotely forever. It is believed that cloud-based collaborating tools will allow teams to be evermore productive than on-site workers. However, not all organisations can work remotely, and this may have a high impact on their survival in this period of COVID-19. According to BBC News (2020), the Chief Executive of Facebook told his employees that from July 2020, he would aggressively open up remote hiring expecting that in the next 5 to 10 years, half of his 
on-site workforce will do their jobs outside the Facebook offices.

\section{COVID-19 and Flexible Work Schedule}

As offices gradually re-open after COVID-19 lockdown, flexible work arrangement is introduced to boost the economy and balance employees work-life. Flexible work arrangement, according to Unicef (2020), is alternate schedules from the standard or traditional work setting. BBC News (2020) observes that a flexible working schedule will become a new normal in the world of work after coronavirus pandemic. And this policy suits employees who are anxious about going back to work while giving their organisations breathing space to introduce the novel social distancing measures. Consequently, many companies are introducing four-day working a week while some three. Other working activities are complemented by alternative working arrangements including "videoconferencing platforms" such as "zoom and google meet".

The traditional work arrangement of the "big city office" and the long-term belief that employees hours of work within the office environment is eroding. COVID-19 is mostly responsible for the change in the traditional fix-hours work. For instance, the University of Nebraska Medical Center - UNMC authorised departments to schedule flexible working hours for staff, provided such changes does not decrease the department's efficiency and increase staff cost (UNMC, 2020). The adoption of flextime by most organisations during the coronavirus lockdown and thereafter will allow workers to maintain efficient work schedule order than regular hours. Flexible work hours allow workers in-collaboration with other departments to arrange for flexible work schedules. Flexible work arrangement, according to Unicef, gives workers greater scheduling freedom in how to meet or fulfil their job responsibilities, personal life and achieve a balanced work-life.

Flexibility may, therefore, take the form of time schedule, work schedule, work location and flexible dressing code; and all these changes the organisational culture. Flexible work arrangement for employees' according to UNICEF (2020) includes flextime, flex-time-off, and flex location/roles. Flextime includes banking of working hours, flexible working hours, switch shifts, job sharing and compressed workweek. Flex-time-off include long term leave with the designation being kept, prolonged personal vacation or holiday, part-time or reduced work hours with the same hourly rate. Flex location/roles include, among others telework, change of responsibilities and temporary remote work (see Table 2).

Table 2: Forms of flexible fork schedule

\begin{tabular}{|c|c|c|}
\hline Flextime & Flex location/roles & Flextime off \\
\hline $\begin{array}{l}\text { 1. Compressed work week } \\
\text { 2. Banking of working hours }\end{array}$ & $\begin{array}{l}\text { 1. Change of responsibilities } \\
\text { 2. Telework }\end{array}$ & $\begin{array}{l}\text { 1. Prolonged or extra holiday or personal leave } \\
\text { 2. Reduced hours or part-time with the same } \\
\text { hourly rate }\end{array}$ \\
\hline 3. Job sharing & $\begin{array}{l}\text { 3. Temporary remote work for } \\
\text { caring proposes }\end{array}$ & 3. Paid location breaks \\
\hline $\begin{array}{l}\text { 4. Switch shifts } \\
\text { 5. Flexible working hours }\end{array}$ & & 4. long-term leave with position preserved \\
\hline
\end{tabular}

Source: Unicef (2020)

Whatsoever form flexibility may take; O'keefe (2020) observe that workplace flexibility increases workers satisfaction and productivity. Flexibility is strikingly innovative with a high potency of changing many organisational cultures for good in the post-COVID-19 era. Flexibility also alters "redtapism" that characterised traditional bureaucratic institutions and catapults these organisations into efficiency. 


\section{COVID-19 and the Mental Health of Workers}

COVID-19, in the first instance, is a physical health crisis, which also has the seed of a significant mental health crisis (United Nations - UN, 2020). COVID-19 has great potential for impacting negatively on the mental health of workers, especially frontline health workers. Researches revealed that since the outbreak COVID-19 pandemic, 4 in every 10 health workers experience insomnia, while one in every healthcare professional has symptoms of anxiety and depression. It further shows that milder mood symptoms are common among healthcare workers and that the rates of anxiety and depression were higher among female nurses and healthcare workers (Pappa et al., 2020).

As the world synergises efforts to fight and mitigate COVID-19, and as researches especially biomedical scientists scramble to balance work-life and personal goals as well as meet their responsibilities to the public, a good number of them are cut in the web of mental crisis. Most biomedical scientists, like healthcare professionals, struggle with depression, high stress, low morale, harassment, and anxiety. With the continuous lockdown, added stress/mental health crisis are more likely to be experienced among these crop of workers (Chan, Oey \& Tan, 2020). Similarly, the International Organisation for Migration - IOM (2020) observed that COVID-19 have a profound impact on the mental health of people globally. This suggests that migrant workers are more likely to be among some of the most mentally affected employees by COVID-19. IOM, therefore, urge governments worldwide to be proactive in ensuring that proper measures are taken to meet the mental needs of affected persons.

COVID-19, according to the World Economic Forum $\left(2020^{a}\right)$, UN News $\left(2020^{b}\right)$, and Reuters World News (2020), will lead to an upsurge in incidence and severity of mental illnesses globally. An estimated 33 per cent prevalence rate of mental illness, which is a threefold increase compared to preCOVID-19 levels, will be experienced worldwide. There is a 35 per cent prevalence in China, 6o per cent in Iran, and 45 per cent in the United States of America (see Figure 2). The mental health crisis is looming because COVID-19 forced a large number of people globally into isolation, and many are surrounded by dead relatives, poverty and anxiety. The most vulnerable to the mental illness crisis are young people, children and healthcare workers who see infected persons dying of COVID-19. In a similar survey by Roy-Byrne (2020) on "mental health effects of COVID-19 on healthcare workers in China", the study revealed that most of the participants suffered adverse psychological reactions because of COVID-19 outbreak. It shows that 50 per cent of healthcare workers who participated in the survey suffered high rates of depression, 45 per cent - anxiety, 34 per cent insomnia, and 72 per cent distress.

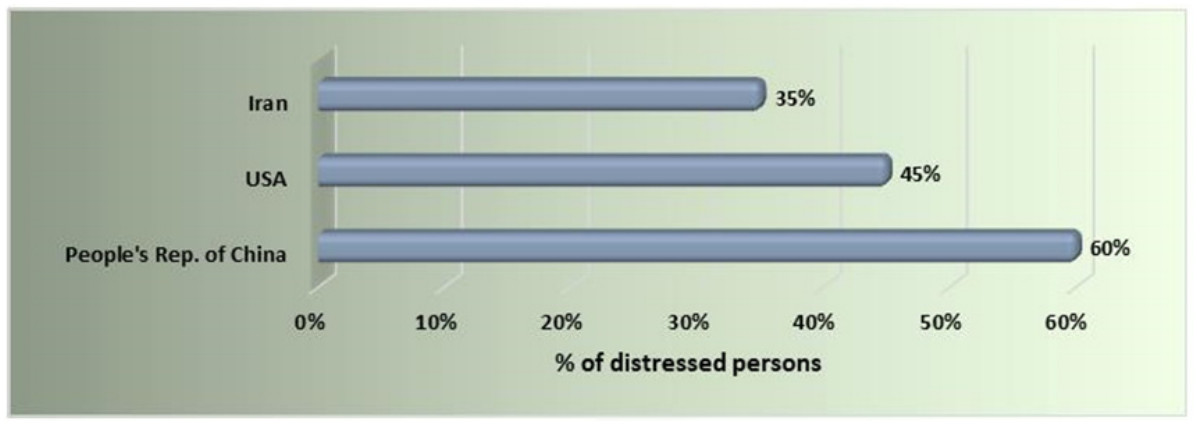

Figure 2: Prevalence of mental illness in population during COVID-19 (year 2020)

Source: World Economic Forum $\left(2020^{\mathrm{s}}\right)$ and UN News $\left(2020^{\mathrm{b}}\right)$

Again, a survey by Ginger, a mental health provider cited in Gavida (2020), shows that for every 10 employees who participated in the study, 7 indicated that the coronavirus pandemic is the most 
trying and stressful time of their entire professional career. The study also revealed that there is a substantial increase in new prescriptions of anti-insomnia, antidepressant, and antianxiety medications. This suggests that employers' strategic and human resource planning during and after COVID-19 should make mental health support an essential aspect of the design or risk a critical aspect of employees' health and productivity. Selko (2020) posits that one crucial source of employees' stress is how companies or employers are reacting to COVID-19 pandemic in terms of workers safety and job security. He, however, argued that COVID-19 outbreak is promoting workers wellness programmes and mental health awareness worldwide. Cooch (2020) and Spoorthy (2020) also observe that COVID-19 pandemic threatens and exacerbate work-related stress and psychological suffering among frontline health workers worldwide. Consequently, World Bank (2020) and ILO $\left(2020^{\mathrm{h}}\right)$ advocated for global support for the mental health of frontline healthcare workers.

\section{COVID-19 and Workplace Discrimination}

COVID-19 is mostly responsible for the unprecedented changes in the world of work. It accounts for the new wave of employee discrimination which has upended the lives of millions of workers worldwide. Discrimination in the context of COVID-19 according to Victoria Legal Aid (2020) includes being unfairly treated because (i) you have coronavirus, (ii) have contact with an infected person, (iii) previously had coronavirus, (iv) employer thinking that a worker will contact COVID-19 in the future, (v) cultural or racial background. According to Phillips (2020), as countries begin to reopen their economies, employers will implement the testing requirement, employees who are COVID-19 positive are more likely to suffer discrimination.

Age discrimination occurs when an employer unfairly treats an employee because of age. Backman (2020) observes that lockdown measures to mitigate the spread of COVID-19 results in continuous economic fallout. This economic scenario forces employers to layoff a significant number of employees. Logically, the action may be legitimate to the extent that no group of employees are unfairly selected for the dismissal because of age. The practice is that most employers oftentimes layoff older employees with higher wages. Huge insurance cover for older employees may inform employers to unfairly layoff. Again, stereotype view about older employees that they are inactive may inform employers' unfair treatment of layoff.

Absence of social security and adequate income support nets among workers in the informal economy, especially in developing countries complied many to continue to work despite the lockdown. This situation is exacerbated by COVID-19 mitigation measures which among others enforces restrictions on social interaction and movement. Apart from women, many workers in the non-standard employment and informal sector are young persons, people living with HIV, migrants, and disabled, who suffered multiple discrimination stigma at the workplace and the larger society. This set of workers risk being further discriminated because of COVID-19. More so, the pandemic has great potential to exacerbating obnoxious forms of work such as forced labour and child labour (ILO, 2020 $\mathrm{i}^{\mathrm{i}}$ ). Consequently, the European Union Agency for Fundamental Rights (2020) argue that employees with informal employment agreements, limited social protection and healthcare before the COVID-19, are particularly and significantly at risk now. This crop of workers faces a strong chance of falling into poverty.

COVID-19 outbreak increases certain types of harassment and discrimination. The misconception that COVID-19 was created and spread by China may result to hate and racial discrimination against Asians in some workplace (Justia, 2020). There is also emerging workplace policies in favour of workers immunity to contagious disease (COVID-19) in USA, Britain, and Germany. Those without COVID-19 antibodies are banned from the workplace. As countries begin to re-open businesses, antibody tests are gradually becoming a major determinant of which employee is immune to COVID-19 and therefore fit to return to the workplace (Kaminer, 2020).

COVID-19 is responsible for privacy invasion of employees in many work environment worldwide. Most employers are no longer ensuring the confidentiality of employees' medical 
information at the workplace. Employers now give out medical information about workers' health status, expressing whether an employee is experiencing COVID-19 symptoms or not (Baillon Thome, 2020). In Japan, nurses and doctors apart from combating COVID-19 also shoulder the burden of abuse, harassment, and hysteria from their fellow citizens. Also, multiple cases of discrimination occurred, as children of healthcare workers are kicked out of public schools and day-care centres; compelling some of them to leave their profession to cater to their offsprings. COVID-19 is, therefore, triggering another epidemic of vilification and fear among medical staff in Japan (CBS News, 2020). Masina (2020) observe that in Malawi - Africa, health workers, instead of been cheered, are facing insults and discrimination at the workplace and the larger society.

Employees are also suffering from structural discrimination in many countries globally. Some workers, especially healthcare professional and other essential workers, risk their health by working in an unsafe and hazardous working environment. According to Yearby and Mohapatra (2020), the law is this context structural discriminate against this set of workers, classifying them under essential workers, while their health and that of their families are at risk of being infected by COVID-19. Thus, the laws are used to the disadvantage of those in elite and influential positions, while disadvantaged to the powerless workers.

\section{Impact of COVID-19 Pandemic on Teleworking}

The COVID-19 pandemic has revolutionalised the teleworking and work-arrangement "complex" across the globe; perhaps an excellent way to start is to examine the meaning of teleworking and work arrangement. The understanding in this approach is that the classification of concepts is pertinent in communicating more fashionably one's ideas to his reading audience.

Teleworking, otherwise called telecommuting or work from home (WFH) is a flexible work arrangement (FWA) in which staff of an organisation perform their assigned tasks at home while communicating and maintaining contact(s) with their office via emails, chats, phone, or through the deployment of internet facilities. Teleworking is not a new work-arrangement concept. Teleworking dates back to the 1970s when in the United States, teleworking was developed in the ICT industry (Nilles, 1975; ILO/Eurofound, 2014). However, the COVID-19 pandemic and its fallout have reinforced its usage and application in an attempt to steady the ship of the organisational economy. We must also recognise that not all work-activity "cannot go telework" or performed from home. We must also note that a more significant number of workers now work from home. The International Labour Organisation (2020 $\mathrm{O}^{\mathrm{j}}$ ) observe that the COVID-19 pandemic implies that more workers than ever before are now teleworking by deployment information and communication technologies (ICT) to perform assigned tasks at home away from their office.

Months before the COVID-19 pandemic, researchers revealed that about 70 per cent of professional workers globally work from home at least once in seven days while about 53 per cent of the global workforce remotely work "for at least half of the work" (Browne, 2018). According to Browne (2018), the ability to perform one's office tasks from the home couple with the emergence of workplace services like digital office rental services has led to changing work attitudes of where should people and whether they should adhere to the traditional working hours. Similar reports indicate that the number of workers working remotely or at home has been rising even before the COVID-19 pandemic. For instance, Flexjobs and Global Workplace Analytics (GWA) report that the number of workers teleworking in the United States of America increased by 159 per cent between 2005 and 2017. A more revealing telework statistics show that a total of 4.7 million persons in the United States currently work from home. As of 2015, the United States had 3.9 million telecommuters (PayScale, 2020).

With technological advancement that encourages flexible work arrangement, the need to cutdown running cost, reduce the time of commuting to offices, the work environment of public and private organisations across the globe are being revolutionalised and redesigned to empower workers to work from home. According to PayScale (2020), teleworking is most common in the following five 
industries - computer and IT, medical and health, sales, education and training, and customer service.

Advantages abound for asking workers to telework a few days a month or week. Accordingly, Akrey (2020) has argued that corporate bodies which redesign their workplace to allow their workers to telecommute a few days a week tend to save money and boost productivity. As she further illustrates this point, Akrey (2020) noted that studies have demonstrated that workers who work from home tend to be happier with their career, and they experience less work-stress. She maintained that employers tend to save money arising from cut-down experiences on office-space and reduction in the cost of maintaining their workers in offices such as travel for meetings, office supplies, etc.

Belzunegui-Eraso and Erra-Garces (2020) have argued that the COVID-19 pandemic demonstrates that teleworking has been adopted globally by most companies (and governments) to ensure their workers' safety and to ensure the continuity/sustainability in economic activities. As the COVID-19 spread to more than 180 countries across the globe, government and companies direct their staff to work from home (WFH) as a physical-distancing measure fundamental in handling the spread of COVID-19 among workers. In the same view, Onyeukwu, Adeniyi and Amin (2020) have argued in favour of teleworking by stating that telecommuting is a panacea to COVID-19 spread in Nigerian universities.

It is our open position in this paper that although some academic activities such as computation of students' results at the undergraduate and postgraduate levels can be performed with the raw scores, Nigerian universities (both public and private) are technologically unprepared to migrate to online education platform that reflects teleworking/telecommuting. Even if the telematics is available for use by stakeholders during this period of the COVID-19 pandemic, the country still suffers from energy poverty that has remained a bane to educational development (Agba, 2011; Agba \& Ocheni, 2017).

\section{Policy Suggestions}

The impact of COVID-19 on the world of work has manifested itself in unique ways. It has significantly altered the fabrics of the workplace and work environment forever. It exacerbates existing cracks at the workplace and works environment. Mitigating such risks requires policy options to be enforced that will enable employers and employees to curb with the dynamics. It includes identifying and addressing general and unique challenges at workplace occasioned by COVID-19 pandemic.

Workplace policy that eliminates all forms of discrimination should be put in place and enforced during and after COVID-19 pandemic. The plan should ensure that workers are equitably treated regardless of gender, race or cultural background, contacts with COVID-19 patients, age, migrant status, and salary level. Multi-faceted and strong advocacy campaign at the workplace and the larger society should be geared towards eliminating all forms of violence, discrimination and harassment against workers, especially frontline health workers professionals.

Occupational health and safety are paramount during and after COVID-19. Employers should provide safety guides and regulations that would keep workers safe and healthy. It includes the provision of sanitisers at the workplace, pre-COVID-19 screening, hand gloves, and enforcing physical distancing. Work schedules should be arranged to implement physical distancing. Flexible work arrangement is essential here; remote work or teleworking should be encouraged by employers. Telework should be scheduled with substantial elements that support and guarantee the mental health of workers.

Globally, millions of jobs are at risk and employment surging weekly as a result of COVID-19. Employers may not be able to create jobs to meet the demands and supply in the labour market. Consequently, post-COVID-19 government policies worldwide should include measures that enable the private sector to create jobs, especially in the informal economy where the bulk of the world's workforce is domicile. Financial aids, tasks exemption, and logistics supports should be given to small and medium enterprises (SMEs) as businesses begin to open globally. This will enable them make-up for the COVID-19 lockdown losses and kickstart business activities. 


\section{Conclusion}

Coronavirus pandemic has changed the world of work forever. Measures adopted by countries to mitigate the pandemic is furthering the frontier of workplace dynamics. This negative consequence of the pandemic manifests in exacerbated global unemployment, workplace discrimination and harassment, and mental health. Other negative impacts include - poor occupational safety and health, and absence of social presence. However, COVID-19 is responsible for the increase in teleworking and flexible work schedule. Although COVID-19 risks the health of workers, it also accounts for an increase in health awareness campaigns in the world of work. The study recommended among other policy options which include revamping the informal economy through financial and tax exemption to create lost jobs.

\section{References}

Agba, M. S. \& Ocheni, S. I. (2017). An empirical study of the effects of work environment (Electric Power Supply) on job performance of academic staff in Nigeria public and private universities. Higher Education of Social Science, 12(2), 11-20. DOI: 10.3968/9737.

Agba, M. S. (2011). Energy poverty and leadership question in Nigeria: An overview and implication for the future. Journal of Public Administration and Policy Research, 3(2), 48-51.

Akrey, C. (2020). Telecommuting: The future of the global workforce. Online available at https://univoip.com/blog/telecommuting-the-future-of-the-global-workforce. Retrieved 6th June 2020.

Bachman, E. (2020). Covid-19 layoff or pretext for age discrimination against older employees? Online available at https://www.forbes.com/sites/ericbachman/2020/04/30/covid-19-layoff-or-pretext-for-age-discriminationagainst-older-employees/\#551f88c94C56. Retrieved 4th June 2020.

Baillon, Thome (2020). Covid-19 and discrimination in the workplace. Online available at https://baillonthome.come/news/employment/covid-19-and-discrimination-workplace. Retrieved 6th June 2020.

BBC News (2020). Coronavirus: Flexible working will be a new normal after virus. Online available at www.bbc.com/news/business-52765165. Retrieved 31st May 2020.

Belunegui-Eraso, A. \& Erro-Garces, A. (2020). Teleworking in the context of the COVID-19 crisis. Sustainability, 12: 1-20.

Ben-Itzhak, Y. (2020). Coronavirus and the transformation of the workplace. Online available at https://www.socialbakers.come/blog/coronavirus-transformation-of-workplace. Retrieved 3oth May 2020.

Browne, R. (2018). $70 \%$ of people globally work remotely at least once a week: Study says. Online available at https://www.cnbc.com/2018/5/70-percent-of-people-globally-work-remotely-at-least-onces-a-week-iwgstudy.html. Retrieved 6th June 2020.

CBS News (2020). Japan: Health care workers face discrimination and harassment over COVID-19. Online available at https://www.business-humanrights.org/en/japan-health-care-workers-face-discriminationharassment-over-covid-19. Retrieved 6th June 2020.

Chan, C., Oey, N. E. \& Tan, E. (2020). Mental health of scientists in the time of COVID-19. Journal of Brain, Behaviour and Immunity. DOI:https://doi.org/10.1016/j,bbi.2020.08.039. Retrieved 1st June 2020.

Cooch, N. (2020) Covid-19: Impact on frontline workers' mental health. Online available at https://priacticeupdate.com/content/covid-19-impact-on-frontline-workers-mental-health/100259.

Retrieved 4th June, 2020.

European Union Agency for Fundamental Rights (2020). Protecting workers' fundamental rights in tackling impact of COVID-19. Online available at https://fra.europa.edu/en/news/2020/protecting-workersfundamental-rights-tackling-impact-covid-19. Retrieved 6th June, 2020.

Gavidia, M. (2020). How has COVID-19 affected mental health, severity of stress among employees? American Journal of Managed Care. Online available at https://www.ajmc.com/newscom/how-has-covid-19-affectedmental-health-severity-of-stress-among-employees. Retrieved 4th June, 2020.

ILO $\left(2020^{a}\right)$. COVID-19 and the world of work. Online available at https://www.ilo.org/global/coronavirus/lang--en/index.htm. Retrieved 23rd May 2020.

ILO $\left(2020^{\mathrm{b}}\right)$. COVID-19 and the world of work: Global impact and policy recommendations. Online available at https://www.ilo.org/global/topic/coronavirus/impacts-and-responses/lang---en/index.htm. Retrieved 23rd May 2020.

ILO $\left(2020^{c}\right)$. COVID-19 and gender equality: The COVID-19 response - Getting gender equality right for a better future for women at work. Online available at https://www.ilo.org/global/about-the-ilo/multimedia /video/institutional-videos/WCMs_745628/lang---en/index.htm. Retrieved 23rd May 2020. 
ILO (2020 $\left.{ }^{\mathrm{d}}\right)$. ILO monitor: COVID-19 and the world of work. Second edition updated estimates and analysis. Online available at https://www.ilo.org/wcmsp5/groups/public/---dgreports--docomm/documents /briefingnotes/wcms_740877.pdf. Retrieved 23rd May 2020.

ILO $\left(2020^{\mathrm{e}}\right)$. COVID-19 causes devastating losses in working hours and employment. Online available at https://www.ilo.org/global/about-the-ilo/newsroom/WCMS-74093/lang---en/index.htm. Retrieved 29th May 2020.

ILO (2020). Covid-19 and the new meaning of safety and health at work. Online available at https://lostat.ilo.g/2020/04/30/covid19-and-the-new-meaning-of-safety-and-health-at-work/. Retrieved 29th May 2020.

ILO $\left(2020^{\mathrm{g}}\right)$. The Covid-19 crisis may lead to mental health issues for many workers. Online available at www.iloblog.org/2020/04/28/the-covid-19-crisis-may-lead-to-mental-health-issues-for-many-workers. Retrieved 4th June, 2020.

ILO $\left(\mathbf{2 0 2 0}^{\mathrm{h}}\right)$. Pillar 3: Protecting workers in the workplace. Online available at https://ilo.org/global/topics/coronavirus/impacts-and-responses/WCMS_739049/lang---en/index.htm. Retrieved 5th June, 2020.

ILO $\left(2020^{\mathrm{i}}\right)$. Keys for effective teleworking during the COVID-19 pandemic. Online available at https://www.ilo.org/global/about-theilo/newsroom/news/WCMS_739879/lang..en/index.htm. Retrieved 6th June, 2020.

ILO/Eurofound (2017). Working anytime, anywhere: The effects on the world of work. Luxembourg: European Union publication Office. DOI: 10.2806/372726.

International Organization for Migration - IOM (2020). Mental health needs of migrants and displaced persons must be part of Covid-19 response. Online available at https://www.iom,nit/news/mental-health-needs-ofmigrants-and-displaced-persons-must-be-part-of-covid-19-response. Retrieved 1st June, 2020.

International Trade Union Confederation (2020). Covid-19 should be classified as an occupational disease. Online available at https://www.ituc-csi.org/covid-19-occupational-disease. Retrieved 29th May 2020.

Justia (2020). Workplace discrimination and harassment during COVID-19. Online available at https://justia.com/covid-19/information-for-employees-during-covid-19/workplace-discrimination-andharassment-during-covid-19/. Retrieved 5th June, 2020.

Kaminer, D. (2020). Discrimination against employees without COVID-19 antibodies. New York Law Journal. Online available at https:/www.law.com/newyorklawjournal/2020/05/04/discrimination-againstemployees-without-covid-19-antibodies/?slreturn=20200504084740. Retrieved 6th June, 2020.

Kiesha, P., Liu, Y., Russell, T. W., Kucharski, A. J., Eago, R. M., Davis, N., Jit, M. \& Klepac, P. (2020). The effect of control strategies to reduce social mixing on outcomes of the COVID-19 epidemic in Wuhan, China: A modelling study. The Lancet Public Health, 5(5), 261-270.

Kilinc Law Consulting (2020). The effects of coronavirus (COVID-19) on occupational health and safety and an evaluation within the scope of work accident. Online available at https://www.kilinclaw.com.tr/en/theeffects-of-coronavirus-covid-9-on-occupational-health-and-safety. Retrieved 29th May 2020.

Masina, L. (2020). Malawi health workers face stigma, discrimination over COVID-19. Online available at https://www.voanews.com/covid-19-pandemic/malawi-health-workers-face-stigma-discrimination-overcovid-19. Retrieved 6th June, 2020.

Naden, C. (2020). COVID-19: Addressing workplace challenges on world day for safety and health at work. Online available at https://www.iso.org/news/ref2504.html. Retrieved 29th May 2020

Nilles, J. M. (1975). Telecommunications and organisational decentralisation. Transactions on Communication, 23(10), 1142-1147.

O'Keefe, S. M. (2020). Amid Covid-19, let's rethink workplace flexibility. Online available at www.gallup.com/workplace/310214/amid-covid-19-let-rethink-workplace-flexibility.aspx. Retrieved 31st May 2020.

Onyeukwu, P. E., Adeniyi, A. \& Amin, H. J. (2020). Telecommuting: A panacea to COVID-19 spread in Nigerian universities. International Journal of Innovation and Economic Development, 6(1), 47-6o.

Papa, S., Ntella, V., Gianakas, T., Gianakoulis, V. G., Papoutsi, E. \& Katsaounou, P. (2020). Prevalence of depression, anxiety, and insomnia among healthcare workers during COVID-19 pandemic: A systematic review and metaanalysis. Journal of Brain, Behaviour and Immunity. DOI:https://doi.org/10.1016/j,bbi.2020.05.026. Retrieved 1st June, 2020 .

PayScale (2019). These telecommuting stats may surprise you. Online available at https://www.payscale.come/careernews/2019/o9/these-telecommuting-stats-may-surprise-you. Retrieved 6th June, 2020.

Phillips, F. (2020). Covid-19 discrimination - Should employers test their global workforce? Online available at https://jdsupra.com/legalnews/covid-19-discrimination-should-79191/. Retrieved 5th June, 2020.

Reuters World News (2020). UN warns of global mental health crisis due to COVID-19 pandemic. Online available at https://www.reuters.com/article/un-health-coronavirus-mentalhealth/un-warns-of-global-mental-health-due-tocovid-19-pandemic-idUSKBN22QOAO. Retrieved 4th June, 2020. 
Roy-Byrne, P. (2020). Mental health effects of Covid-19 on healthcare workers in China. Journal Watch. Online available at https://jwatch.org/na5119o/2020/o3/27/mental-health-effects-of-covid-19-on-healthcareworkers-china. Retrieved 4th June, 2020.

Selko, A. (2020). COVID on the mind: Mental health awareness in the workplace. Online available at https://www.ehstoday.com/covid19/article/21130750/covid-on-the-mind-mental-health-awareness-in-theworkplace. Retrieved 4 th June 2020

Spoorthy, M. S. (2020). Mental health problems faced by healthcare workers due to the Covid-19 pandemic - A review. Asian Journal of Psychiartr. Doi:10.1016/j.ajp.2020.102119. Online available at https://www.ncbi.nim.nih.gov/pmc/articles/PMC 7175897/\#. Retrieved 4th June, 2020.

Statista (2020). Predicted employment loss in the travel and tourism industry due to the coronavirus (COVID-19) pandemic worldwide in 2020, by region. Online available at file://c:/users/usher/Desktop/\%E2\%80\%A2oLoss\%/2oin\%... Retrieved 25th May 2020.

UN News $\left(2020^{b}\right)$. UN leads call to protect most vulnerable from mental health crisis during and after COVID-19. Online available at https://news.un.org/en/story/2020/05/1063882. Retrieved 4th June, 2020.

Unicef (2020). Guidance for employers on flexible work arrangements, childcare support and other good workplace practices in the context of COVID-19. Online available at www.unicef.org/ukraine/media/4331/file/leaflet.pdf. Retrieved 31st May 2020.

United Nations - UN (2020). Policy brief: Covid-19 and the need for action on mental health. Online available at www.unsdg.un.org/sites/default/files/2020-05/UN-Policy-Brief-COVID-19-and-mental-health.pdf. Retrieved 1st June, 2020 .

United Nations Global Compact (2020). COVID-19 and the world of work. Online available at https://www.unglobalcompact.org/take-action/events/1761-civd-19-and-the-world-of-work. Retrieved 23rd May 2020.

United Nations News $\left(2020^{a}\right)$. Nearly half of global workforce at risk as job losses increase due to COVID-19: UN Labour Agency. Online available at https://www.news.un.org/en/story/2020/04/1062792. Retrieved 25th May 2020.

United Nations News $\left(2020^{b}\right)$. COVID-19: Impact could cause equivalent of 195 million job losses, says ILO chief. Online available at https://www.news.un.org/en/story/2020/04/1061322. Retrieved 25th May 2020.

University of Nebraska Medical Centre - UNMC (2020). Flexible work schedule. Online available at www.unmc.edu/coronavirus/keep-working/flexible-work.html. Retrieved 31st May 2020.

Victoria Legal Aid (2020). Covid-19 and discrimination at work. Online available at https://www.legalaid.vic.gov.au/find-legal-answers/covid-19-coronavirus/discrimination-work. Retrieved 4th June, 2020.

Watterson, A. (2020). COVID-19 in the UK and occupational health and safety-predictable but not inevitable failure: What can we do now? Online available at https://www.researchgate.net/publication/340502136 _COVID-19-in-the-uk-and-occuational-health-and-safe... Retrieved zoth May 2020.

WHO (2020). World day for safety and work at work: WHO key facts and key measures to support the day. Online available at https://www.who.int/news-roomdetail/28-04-2020-who-calls-for-health-safe-anddecent-working... Retrieved 29th May 2020

World Bank (2020). Supporting mental health and resilience in frontline COVID-19 (coronavirus) health care workers. Online available at https://blogs.worldbank.org/health/supporting-mental-health-and-resiliencein-frontline-covid-19-coronavirus-health-care-workers. Retrieved 4th June, 2020.

World Economic Forum $\left(2020^{a}\right)$. This is how COVID-19 could change the world of work for good. Online available at https://weforum.org/agenda/2020/o4/here-s-how-coronavirus-has-changes-the-world-of-work-covid19adam-grant/. Retrieved 23rd May 2020.

World Economic Forum (2020 $)$. COVID-19: US economy sheds record 20.5 million jobs in April. Online available at www.weforum.org/agenda/2020/05/coronavirus-deals-u-s-job-losses-of-20-5-million-historic-unemploymentrate-in-april/. Retrieved 25th May 2020.

World Economic Forum $\left(2020^{c}\right)$. UN warns of global mental health crisis due to COVID-19 pandemic. Online available at https://www.weforum.org/agenda/2020/o5/united-nations-mental-health-crisis-covid-19pandemic. Retrieved 4th June, 2020.

Yearby, R. \& Mohapatra, S. (2020). Structural discrimination in COVID-19 workplace protections. Journal of Health Affairs. Online available at https:/www.healthaffairs.org/do/10.1377/hblog20200522.280105/full/. Retrieved 6th June, 2020. 